weise, die Angiographie dokumentiert die Topographie. 5 Patienten, 28 - 65 Jahre alt, wurden mit Hilfe der HerzLungen-Maschine operiert. Bei der Entfernung der Tumoren entsprangen 3 vom Vorhofseptum und konnten histologisch als gutartige Myxome identifiziert werden. Ein Tumor erwies sich als verkalkter Thrombus, ein anderer wurde als infiltrierend wachsendes malignes polymorphes fibröses Histocytom diagnostiziert. Intrakardiale - überwiegend benigne - Tumoren sind sehr selten. Werden sie rechtzeitig erkannt, ist eine operative Entfernung im Allgemeinen unproblematisch.

Schliisselwörter: Intrakardiale Tumoren - Operation mit Herz-Lungen-Maschine.

\title{
335. Unsere Technik der Uranorrhaphie zur chirurgischen Frühbehandlung der Gaumenspalte
}

\author{
L. Teixidor de Otto und P. Jover Pérez \\ Kinderchirurgische Abteilung Ciudad Sanitaria, E-Oviedo, Odontopädiatrische Abteilung, Kinderchirurgische \\ Klinik des Hospital Infantil „La Paz“, E-Madrid
}

\section{Early Closure of the Cleft Palate}

Summary. The aims of our pushback technique are as follows: (1) lengthening the palate until it is in contact with the pharynx; (2) layer-wise anatomical reconstructin of buccal mucosa, nasal mucosa, and muscles, (3) transversal reduction of the nasopharyngeal space. The pushback procedure used is that of Wardill, which guarantees good and audiological and phonetic results in $75 \%$ and has been employed by us for the closure of more than 1,085 cleft paltates of all types. All patients were operated on before the second year of life.

Key words: Cleft palate - Early repair - Pushback.

Zusammenfassung. Ziel der Uranorrhaphie ist: 1. Verlängerung des Gaumens bis zu seinem Kontakt mit der Pharynx; 2. Schichtweise anatomische Rekonstruktion von Mund- und Nasenschleimhaut und Muskeln; 3. Transversale Verkleinerung des nasopharyngealen Raumes. Um diese Ziele zu erreichen, wird die Uranorrhaphie nach der Methode von Wardill (pushback-procedure) ausgeführt, mit der zu etwa $75 \%$ gute phoniatrisch-audiologische Ergebnisse erreicht werden. Der Film zeigt die Technik, die bei mehr als 1085 Gaumenspalten aller Typen bei Patienten vor dem 2. Lebensjahr angewendet wurde.

Schlüsselwörter: Gaumenspalte - Frühverschluß - Pushback-Methode.

\section{Brustrekonstruktion mit körpereigenem Gewebe - Der kontralaterale thoracoepigastrische Haut-Muskel-Lappen kombiniert mit der abdominellen Verschiebeplastik}

\author{
H. Bohmert und W. Haas \\ Abteilung Plastische Chirurgie der Chirurgischen Klinik und Poliklinik, Klinikum Großhadern, \\ Marchioninistraße 15, D-8000 München 70

\section{Breast Reconstruction with Patient's Own Tissue - The Contralateral Thoracoepigastric Myocutaneous Flap Combined with the Abdominal Advancement Flap}

Summary. A new method of breast reconstruction has been developed on the basis of the anatomical studies on the thoracoepigastric flap performed by the author in 1974. The thoracoepigastric flap is transferred on its vascular pedicle together with the medial part of the abdominis muscle from the contralateral side to the side that has undergone mastectomy. The surplus skin and subcutaneous tissue of the ipsilateral side are used for the reconstruction. This film demonstrates the technique in the form of a cartoon and a life performance.

Key words: Breast reconstruction - Myocutaneous flap.

Zusammenfassung. Auf der Basis der vom Autor 1974 durchgeführten Studien über die Gefäßversorgung des thoraco-epigastrischen Lappens wurde eine neue Technik der Brustrekonstruktion entwickelt. Dabei wird der t.e.-Lappen von der kontralateralen Seite zusammen mit dem medialen Anteil des Rectusmuskels und den darin 